KEMAS 15 (2) (2019) 258-268
Jurnal Kesehatan Masyarakat

\title{
The Effect of Physical and Socio-cultural Environments on the Access of Family Planning Service in Poor Couples of Reproductive Age in Sabu Raijua Regency
}

\author{
Aysanti Yuliana Paulus ${ }^{凶}$, dan Arman Rifat Lette \\ Midwivery Diploma Study Program, Citra Banga University, Kupang
}

\section{Article Info}

Article History:

Submitted September 2019

Accepted October 2019

Published November 2019

Keywords:

family planning, couples of reproductive age, environmental, socio-cultural

\section{DOI}

https://doi.org/10.15294/

kemas.v15i2.20964

\begin{abstract}
One strategic decision from Indonesian government in order to slow the rate of population growth is national family planning (FP) program. One common problem regarding contraceptives in the community is the presence of negative perception regarding contraceptives. Numerous growing rumors or believes in the community often produces fear regarding contraceptives usage. This research aimed to analyze and study the influence of physical and socio-cultural environments on the access of family planning service in poor couples of reproductive age in Sabu Raijua Regency. This was an analytic observational study using mixed method. The results of quantitative analysis showed that factors which affect the access of FP service in poor couples of reproductive age were believe ( $p$-value of 0.046 ), significant others ( $p$-value of 0.014 ), and transportation ( $p$ value of 0.0001). Meanwhile, tradition did not have significant effect ( $\mathrm{p}$-value of 1.000). From the results of qualitative analysis, several believes were found in the people of Sabu Raijua Regency, namely: FP could cause disease, FP could cause infertility, ancestor's prohibition, and local believes (Jingitiu). Significant others factors consisted of lack of support or the presence of prohibition from husband or parent-in-law on the ground of fear that the wife could be sick or could not work appropriately. Transportation factor consisted of lack of private vehicle or public transportation which made the respondent reluctant to access FP service (probability of $92.99 \%$ ).
\end{abstract}

\section{Introduction}

One strategic decision of Indonesian government in order to suppress the population growth was national family planning (FP) program. One objective of FP program was to decrease the pregnancy using contraceptive methods to prevent pregnancy and family planning (Sulistyawati, 2011). The rate of economic growth which could increase people prosperity could be achieved through control of population growth rate by suppresing the birth rate in each family. FP program were conducted and coordinated by central government, therefore it has status as national program. FP is utilization of fertilization control measures to assist somoone or family to achieve certain objective. The said objectives are voluntary birth control by the family which is not against current laws or Pancasila moral values and attainment of family prosperity. Birth control is directed by the government in order to better fulfill the need of the peope, to promote appropriate interregional population distribution, and to decrease the mortality rate. Those measures are taken so Indonesia could be included in the group of developed country in terms of health and prosperity of the people. Every problem solution should be conducted through strategic decision, therefore the problems could be managed by the government and the people together. (Darahim, 2010).

In order to achieve the success of FP services, it needs to be supported by community members by actively participating 
as FP participants or FP acceptors. FP acceptors are community members who take part in the FP movement by using contraceptives. Based on the objectives, $\mathrm{KB}$ usage could be divided into three phases namely pregnancy delaying or preventing phase, pregnancy spacing phase and pregnancy stopping or fertility ending phase. Family planning services are recommended for couples of reproductive age (pasangan usia subur/PUS), because they are more likely to produce offspring and could increase birth rates. Family planning acceptors could be differentiated into three types: 1) New FP acceptors or participants, namely couples of reproductive age who first use contraceptive after experiencing a pregnancy that ends in miscarriage or childbirth. 2) Old FP participants or acceptors i.e. participants who are still using contraceptive without disruption by pregnancy. 3) FP acceptors or participants who want to change the methods of contraception (Manuaba, 2010).

Based on the data obtained from the National Family Planning Coordinating Agency (BKKBN) of East Nusa Tenggara (NTT) Province, the number of female acceptors in 22 regencies/ cities were more than the number of male acceptors. This proved that the level of men participation in family planning program was still low compared to women. In the last 3 years, the number of new women acceptors was continuously increased. Sabu Raijua Regency had the second lowest number of new FP participants per contraceptive method from January to August 2017 after Nagekeo Regency. Another concerning fact was the absence of users of IUD, men sterilization method (MOP) and women sterilization method (MOW) in Sabu Raijua Regency (BKKBN, 2018). The fertile period of a woman has an important role for the occurrence of pregnancy, therefore the chance of a woman to give birth is quite high. The number of new FP participants in 2017 using Long Term Contraceptive Method was 0 while the number of new FP participants using Non Long Term Contraceptive Method was 207 people. The coverage of active FP participants among couple of reproductive age in Sabu Raijua Regency in 2017 was 1,342 with 1,342 people used Non Long Term Contraceptive
Method. (Raijua, 2018).

Access to health services meant that health services must be achieved by the community, and did not obstructed by geographical, social, economic, organizational and language conditions. Geographical barrier could be measured by the distance, duration, types of transport and other physical barriers that could hinder a person to get health service (Pohan, 2004). From the provider side, there are five dimensions of access, namely: 1) Proximity, users acquire health services that can be identified in the form of service availability, reachability, and have impact on the user's health. 2) Ability to receive, in relation to socio-cultural factors that enable the community to accept the services offered. 3) Availability, refers to health services that can be reached anytime and anywhere. It does not only mean physical availability, but the human resources are able to provide services according to their ability. 4) User ability, refers to the social and economical abilities of users to use health facilities. 5) Conformity, refers to the compatibility between the services provided and the needs of users.

Based on this background, we are interested in conducting research with the title "The Effect of Physical and Socio-cultural Environments on the Access of Family Planning Service in Poor Couples of Reproductive Age in Sabu Raijua Regency".

\section{Methods}

The design of this research was mixed method which consisted of quantitative approach using cross-sectional design as primary approach and qualitative approach using phenomenology design with in-depth interviews as supporting approach, therefore the researchers could explore the data more widely and lead to certain problems in more detail (Sastroasmoro, 2011). The population were all couples of reproductive age in Sabu Raijua Regency with inclusion criteria as follows: 1) couple of reproductive age; 2) lived at the research location; 3) PUS with low family income (less than regional minimum wage); 4) could communicate well; and 5) willing to become research respondents. The number of samples was 106 PUS. The instruments to collect data from respondents 
were a structured questionnaire, in-depth interview guideline, and observation sheet. The collected data were processed and analyzed in two ways, namely: inferential analysis to prove the influence between variables, using the Chi Square test and Multiple Logistic Regression.

In qualitative method, the main informants were the couples of reproductive age, especially the mothers who had not become FP acceptors. Supporting informants were health workers, FP officers and community leaders. The data were collected using observation and in-depth interviews. Purposive sampling technique was used in this study. In-depth interviews were first conducted to main informants, namely mothers who had not become FP acceptors or who had drop out (DO) status. Afterwards, the interviews were carried out for health workers, FP field officers, and community leaders. The validity of the data was measured using triangulation of method and sources. The data were analysed using Miles and Huberman models. Data analysis consisted of data reduction, data display, and conclusion/ verification.

\section{Results and Discussion}

Overview of Study Population

The cumulative number of couples of reproductive age (PUS) in Sabu Raijua Regency as of February 2019 was 9,592 couples, and there were 7,632 (79.57\%) couples who were pre-prosperous. The average percentage of active FP participants in each sub-districts were as follows: West Sabu 90.40\%, Hawu Mehara 64.70\%, Central Sabu 51.31\%, East Sabu 49.04\%, Raijua 48.83\%, and Sabu Liae 38.59. The percentage of pre-prosperous PUS that had not used contraceptives was $15.50 \%$.

The samples were taken based on the calculation of sample size which obtained as many as 106 PUS which consisted of PUS that had never had FP access at all and PUS that had previously accessed or used FP but they stop (dropped out). Sampling was scattered in almost all sub-districts in Sabu Raijua Regency, except in Raijua Sub-district because it was on separate island and was difficult to reach. The results of univariate analysis could be seen in Table 1.

Table 1 shows that $50 \%$ of the respondents

Table 1. Frequency distribution of respondent characteristics

\begin{tabular}{llc}
\hline Variable & $\mathrm{n}$ & $\%$ \\
\hline Access to FP services & & \\
1. Never & 53 & 50 \\
2. Once used FP but dropped out & 53 & 50 \\
\hline Level of education & & \\
1. Not attending school & 22 & 20.8 \\
2. Elementary school & 47 & 44.3 \\
3. Junior high school & 14 & 13.2 \\
4. Senior high school & 16 & 15.1 \\
5. Higher education/university & 7 & 6.6 \\
\hline Occupation & & \\
1. Unemployed/housewife & 62 & 58.5 \\
2. Laborer/farmer/fisherman & 35 & 33.0 \\
3. Private employee & 5 & 4.7 \\
4. Entrepreneur & 4 & 3.8 \\
5. Civil servant/police/armed forces member & 0 & 0.0 \\
\hline Parity & & \\
1. <2 children & 33 & 31.1 \\
2. 3-5 children & 35 & 33.0 \\
3.> 5 children & 38 & 35.9 \\
\hline Religion & & \\
1. Protestant & 90 & 84.9 \\
2. Catholic & 6 & 5.7 \\
3. Moslem & 2 & 1.9 \\
4. Others (Iingitiu) & 8 & 7.5 \\
\hline
\end{tabular}

Source: primary data, 2019 
Table 2. Cross tabulation of the effect of belief factor on access to FP services

\begin{tabular}{|c|c|c|c|c|c|}
\hline \multirow{3}{*}{ Trust factor } & \multicolumn{4}{|c|}{ Access to FP services } & \multirow{3}{*}{ p-value } \\
\hline & \multicolumn{2}{|c|}{ Never } & \multicolumn{2}{|c|}{ Once used FP but DO } & \\
\hline & $\mathrm{n}$ & $(\%)$ & $\mathrm{n}$ & $(\%)$ & \\
\hline Negative & 21 & 70.0 & 9 & 30.0 & \\
\hline Positive & 32 & 42.1 & 44 & 57.9 & 0.018 \\
\hline
\end{tabular}

Source: primary data, 2019

had never accessed FP services while the remaining $50 \%$ had once accessed $\mathrm{FP}$ services but stopped prematurely (dropped out). Most of the respondents were elementary school graduates $(44.3 \%)$, unemployed $(58.5 \%)$, and had more than 5 living children (38\%). Most of the respondents were Protestant (84.9\%) but there were still people with other religions/ beliefs, namely Jingitiu (7.5\%), which did not accept various kinds of modern medicine and only believed in traditional medicines.

Bivariate analysis was carried out to see the relationship between the independent variables and the dependents variable using the chi-square test $\left(\mathrm{X}^{2}\right) . \mathrm{P}$ value of $<0.05$ indicates significanct results.

The results of the analysis of the effect of belief factors on access to FP services found that respondents who had negative belief also had tendency not to access FP services compared to respondents who had positive belief $(70 \%$ vs $42 \%$ ). Conversely, respondents who had positive belief about FP had a tendency to access FP services ( $57.9 \%$ vs $30 \%$ ). The statistical test results obtained $p$ value of 0.018 , therefore it could be concluded that there was a significant effect between negative belief of respondents and access to FP services. In addition, the OR value was 3.2 , which meant that the respondents with negative belief had a 3.2 times more tendency not to access FP services compared to those with positive belief. The result of this study is in line with the result of a study by Harahap et.al. (2013) which showed no relationship between belief and IUD usage. A study by Dzalva (2015) also showed that among FP acceptors in Puskesmas Kalideres which used non long term method, there was more users who had negative belief (96.2\%) compared to positive belief (3.8\%). That study also found p-value of 0.007 which meant that there was a significant relationship between the belief of the FP acceptor and the use of long term contraceptive method. However, the result of this study is not in line with a study by Wulandari (2015) which found that there was no relationship between belief and IUD participation with several reasons found such as: in the Malay tribe a child is God's blessing so there is no need to reject it by using contraceptive.

Trust is a belief that a phenomenon or an object is true or real. When someone believes that a healthy behavior will benefit him/her, it will increase his/her motivation to perform that health behavior (Notoatmojo, 2010). The results of the qualitative analysis also support the previous results. The informant stated that there was a belief from the ancestor that family planning could have adverse effects on the mother and child. There was also a local belief in Sabu that called Jingitiu in which the people were less willing to come in contact with modern health services. Local beliefs that arise and develop in an area with different backgrounds in life, traditions, customs and culture show different characteristics from one another. That is, a local belief contained in an area will not be the same as a local belief contained in another area. The similarity of some aspects of local belief can occur as an expression of spirituality and a form of practice of belief, but each local belief will reveal its own peculiarities and characteristics (Sirait et al., 2015) . The existence of hereditary local belief is also related to access to FP services in which the mother does not want to become a FP acceptor because of hereditary ancestors' belief that family planning could cause bad effects.

Informants, especially family planning field workers and health workers also stated that there were still mothers in their work areas who considered that family planning method (especially IUD) were taboo. This caused the mothers to have no intention to join the family planning program. The informant also stated that there were still families who believe 
that many children would results in more fortune. Fertile Age Women (WUS) with low socioeconomic have a stigma or the view that the more children they have, the more likely they will be cared for in the future by their children (Sunarsih, et al, 2015).

Women who had not become family planning acceptors also stated that they had not participated in family planning programs because of fears of suffering from diseases such as gout and dizziness. They believed that birth control could cause illness. Fear is an emotional response to threats. Fear is a reaction that arises within the individual, then the individual would try to protect themselves against stimuli or dangers from the outside, they also distance themselves from something that could hurt themselves, injure themselves, or cause other dangers (Sobur, 2013). Mothers who had not become family planning acceptors also stated that there was fear in using family planning method because they believed that by using family planning, mothers could not have more children (become infertile). This was closely associated to the knowledge and education of mothers. Level of knowledge could affects one's behavior. Knowledge can be obtained through the process of learning and sensing an object, which in this case relates to the intelligence possessed by each individual. Sensing occurs through the five human senses namely the sense of sight, hearing, smell, taste and touch. Knowledge or cognition is a very important domain to shape one's action (Notoatmojo, 2010). This was shown by the low level of education which could affect the level of knowledge of mothers in this study. The results of the study shown that most of the subjects only completed elementary school level (44.3\%). The results of the study by Pinontoan et al. (2014) showed that there was a relationship between knowledge and the use of contraceptives (FP). Mothers who had good knowledge of family planning tend to become family planning acceptors. Other studis (Rades and Susianti, 2015; Sunarsih, et.al., 2015; StrømRoum, et.al , 2016; Hobstetter et al. , 2015) also showed significant relationship between level of knowledge and education of mothers/women of childbearing age and the selection and use of contraceptives.

Informants, especially mothers who had not become family planning acceptors also stated that they did not want to join the family planning program because they felt they were not compatible with contraceptives, even though they had never tried to use one. This was supported by the statement of health workers. Field officers also stated that there were women who were unwilling to join the family planning program because they believed rumors or news that were not true regarding family planning. Rumor is a type of information whose source is unknown and has not been proven to be true. Rumors generally spread by word of mouth. Some of the example of rumors that were developed in the community regarding family planning programs were: family planning could cause sterility, family planning could interfere with health or caused disease. Such believe in rumor could have an effect on the mother's unwillingness to become a family planning acceptor. A study by Hudha Fadhila, et.al., 2017. stated that unmet need which were found in PUS consisted of unmet family planning needs because they wanted to distance and limit the number of children, $72.5 \%$ wanted to limit the number of children but had not used contraception with reasons of worry, fear of side effects caused by contraceptives, did not have the husband's support, and incompatibility with contraceptives. Side effects that were being worried and feared were being fat, changes in menstrual patterns, and acne occurrence.

Table 3. Tabulation of the effects of custom factors on access to FP services

\begin{tabular}{llllll}
\hline \multirow{2}{*}{ The customs factor } & \multicolumn{3}{l}{ Access to FP services } & \\
\cline { 2 - 5 } & \multicolumn{2}{l}{ Never } & \multicolumn{2}{l}{ Once used FP but DO } & p-value \\
\cline { 2 - 5 } & $\mathrm{n}$ & $(\%)$ & $\mathrm{n}$ & $(\%)$ & \multirow{2}{*}{000} \\
\hline Yes & 0 & 0 & 0 & 0 & 1,000 \\
\hline
\end{tabular}

Source: primary data, 2019 
The informant also stated that they did not want to join the family planning program because of government assistance that could guarantee their life along with their children. Mother had motivation to receive government assistance when they were pregnant and had children/ toddlers. This caused the mothers to be reluctant to join the family planning program because they were sure that they would get the assistance. However, sequential pregnancy at close range could have negative effects on mother and children's health. The need to pay attention to the ideal distance of pregnancy also helps prevent premature babies and low birth weight (LBW) babies (Sulistyawati, 2011).

This study found that there were no respondents who have customs that prohibit access to FP services with the statistical test results obtained $p=1,000$, therefore it can be concluded that there is no significant effect of custom factors on respondents access to FP services.

Variable of norm or custom of respondents was proved to have a significant effect on access to FP services in preprosperous PUS $(\mathrm{p}=0.025<\alpha=0.05)$. That variable was a contributing factors that made the subjects had 2.6 times more probablity for not accessing family planning service compared to those who did not have such belief $(\mathrm{OR}=2.6 ; 95 \% \mathrm{CI}=1.6-6.7)$. The results also showed that respondents who had negative beliefs were more than those who had positive beliefs (70.0\% vs $42.1 \%)$. Customs, beliefs and values are predisposing factors to the formation of a behavior and were related to the motivation of a person or group to act (Muhatiah, 2012)

Norms or rules are the provisions that become guidance for acting in people's lives. Norms contain suggestions for doing good and prohibitions to do bad things so that life will be better. Norms also related to sanction, a condition that is imposed on the violator of the norm. Customary norms arise from the daily social habits of people in a particular area (Winarno, 2014). Based on the quantitative and qualitative results of the study, there were no specific customs or norms that were related to the behavior of accessing FP services which meant that there were no custom restrictions in Sabu Raijua Regency to access FP services. The results of this study were consistent with the study conducted by Ekarini who stated that there was a supporting social and cultural relationship to family planning in the Selo District ( $p$ value $=0.024$ ) and the percentage of subjects that supports FP was 51.5\% (Ekarini, 2010). Occcasionally, customs become unwritten laws that apply in a particular society, and have binding forces among them. Values and norms are closely related because the values possessed by a person influence their behavior, while the norms are regulators of human behavior. (Noorkasiani, 2012). The study by Suryawati (2007) showed that sociocultural aspect had effects on pregnancy care, childbirth and postpartum period. Therefore it still needs a continuous IEC (Communication, Information and Education) that aims to maintain positive practices and reduce or eliminate the understanding that values do not support reproductive health. (Suryawati, 2007)

Operational policies for the delivery of health services to remote indigenous groups (RIG) requires proper planning and synergy that involved the public servant, members of remote indigenous groups, and regional potential (NGOs/business community) under the coordination of regional head of government (regent) in order to arouse the awareness of the government and the public including the business community in an effort to have better patterns of health care in short term and long term. The purpose of RIG empowerment is

Table 4. Cross tabulation of the effect of significant other factors influencing access to FP services

\begin{tabular}{|c|c|c|c|c|c|}
\hline \multirow{3}{*}{ Effect of Significant Others } & \multicolumn{4}{|c|}{ Access to FP services } & \multirow{3}{*}{ p-value } \\
\hline & \multicolumn{2}{|c|}{ Never } & \multicolumn{2}{|c|}{ Once used FP but DO } & \\
\hline & $\mathrm{n}$ & (\%) & $\mathrm{n}$ & $(\%)$ & \\
\hline Yes & 26 & 65.0 & 14 & 35.0 & \multirow[b]{2}{*}{0.028} \\
\hline Not & 27 & 40.9 & 39 & 59.1 & \\
\hline
\end{tabular}

Source: primary data, 2019 
to empower them in numerous activities in all aspects of life and livelihood so that they can live naturally, physically and spiritually as other nationals who can play a role in the development part. The pattern of community empowerment need to be adjusted according to local wisdom. It is necessary to determine the substance that can be a main point of empowerment. At that point empowerment must be carried out (Ariningrum and Sukoco, 2012).

The results of the analysis of the effect of significant other factors on access to FP services found that respondents who received significant other influences (husband, parents, in-laws, friends) tend not to access FP services compared to respondents who were not influenced by significant other (65\% compared to $40.9 \%$ ). Conversely, respondents who were not influenced by significant others have a tendency to access FP services (59.1\% compared to $35 \%)$. Statistical test results obtained $\mathrm{p}$ value $=0.028$, therefore it can be concluded that there was a significant relationship between the influence of significant other on access to FP services. The OR value of the statistical test results for the significant other factor was 2.7 which meant that respondents who received influence of significant others had a tendency not to access FP services 2.7 times compared to those without the influence. The results of the study by Alfiah (2015) found that almost all husbands and families (94.4\%) supported their wives to use contraceptives. Based on these results, the husband gave freedom and support to the wife to use contraceptive in accordance with the wishes of the wife. The results of the study by Budisantoso (2009) stated that there were injustice and gender equality, they were not aware that family planning matters were the responsibility of both husband and wife.

The qualitative results of this study found that there were informants who stated that the husband did not support and forbid them so that the wife did not participate in the family planning program. There were even wives who secretly used contraceptive and if they were caught by the husband there would be quarrel resulting in drop out. The statements were also supported by statements from supporting informants, namely FP field officers and community leaders who stated that when most of the married women (wives) did not have the courage to make decisions without their husbands. There were several reasons stated by the respondents, namely if the wife used family planning (especially the implant), then the wife could not work hard to help the family made a living. The results of a study by Wahyuningsih and Hanik stated that the wives could determined the choice of contraception themselves and the husband did not play role in determining the choice of contraceptive. In contraceptives usage, problem could arise if the husband did not provide support in using FP because there were side effects in contraceptive usage such as acne, weight changes, and vaginal discharge. Lack of support from the husband made the respondent reluctant to use contraceptive and decided to drop out from family planning program (Wahyuningsih et al. , 2012) .

The closest people (significant others) have influence on maternal compliance in using contraceptive. Family planning and communication with friends about family planning have a great opportunity to influence the use of contraceptive by mothers (Hawkins and Broaddus, 2016). Social interactions/social communication that occurs between mothers who are family planning acceptors causes verbal information dissemination related to family planning programs. The results of the study by Rahman et al., 2013. showed several most common source of information related to contraception especially emergency contraception in women in Sikkim, India were electronic media $(77.1 \%)$, friends or relatives $(33.8 \%)$, and health workers $(30.4 \%)$. Friends and relatives of the mother also became a source of information related to the use of family planning tools and could influence the mother's decision to become a family planning acceptor. Apart from friends and relatives, health workers was also a source of information for mothers related to the family planning program. Communication with the people closest to the mother was closely related to the decision to take on a family planning program or the selection of effective family planning methods. Difficulties in communication or lack of establishing communication with the closest 
Table 5. Cross tabulation of the effect of transportation factors on access to FP services

\begin{tabular}{|c|c|c|c|c|c|}
\hline \multirow{3}{*}{ Transportation Factors } & \multicolumn{4}{|c|}{ Access to FP services } & \multirow{3}{*}{ p-value } \\
\hline & \multicolumn{2}{|c|}{ Never } & \multicolumn{2}{|c|}{ Once used FP but DO } & \\
\hline & $\mathrm{n}$ & (\%) & $\mathrm{n}$ & $(\%)$ & \\
\hline No & 48 & 67.6 & 23 & 32.4 & \multirow[b]{2}{*}{0,0001} \\
\hline Yes & 5 & 14.3 & 30 & 85.7 & \\
\hline
\end{tabular}

Source: primary data, 2019

people, especially the mother were related to less effective choice of contraception in young women (Vigoureux, et.al. , 2018).

The study of Quinn, et al in 2016 also showed that mothers who were still teenagers, still lived with their biological parents, and had the support of biological parents, proved to have four times more probability to maintain the use of contraceptives than adolescents who did not live with the parents. The results of that study indicated that social support from the closest people (husband and parent) was also related to maternal behavior and compliance as FP acceptor. Pregnancy prevention programs and the use of contraceptives must involve key people who support the mother (Quinn, et. al. 2017). Support could be interpreted as one of the functional relations or social ties in which the functional aspects include emotional support, encourage the expression of feelings, provide advice or information, and providing material assistance. Most of the husbands did not provide adequate emotional support, for example, the husband never listen to the complaints of their wives when they use family planning (FP) injection. This could cause the mother to feel less emotionally cared for by their husband which would reduce their enthusiasm to continuously use family planning (FP) injection according to schedule. In general, people who received the comfort, attention and help they need from someone usually were easier to follow or adhere to advice in FP injection compared to users who lack the support of their husbands (Rafidah, 2012).

According to BKKBN (2000) the use of contraceptive is the responsibility of men and women as partners, so that the method of contraception chosen reflects the needs and desires of husband and wife which support each other in the use of contraceptive methods. This is supported by the opinion of Notoatmodjo
(2010) that family (husband) and friends are supporting elements in compliance behavior. In general, people feel that receiving the comfort, attention and help they need from someone usually tends to be easier to follow or obey advice from injecting family planning users who lack the support of their husbands. The results of the study by Uddin, et.al. (2016) also showed that joint decision making between husband and wife that reflected the concept of the power structure of equality, appeared to be statistically significant in logistic regression analysis. This means that joint decision making provides more encouragement for mothers to become family planning acceptors compared to independent decision making without partner's consent. Policy makers in the family planning field can promote community-based outreach programs and campaigns for family planning that focus on gender roles in the household.

The results of the analysis of the effect of transportation factors on access to FP services found that respondents who did not have their own transportation tends to not access FP services compared to respondents who have their own transportation (67.6\% compared to $14.3 \%)$. The statistical test results obtained $p$ value of 0.0001 , therefore it could be concluded that there was a significant influence between transportation factors and access to FP services. In addition, the OR value of the transportation factor was 12.5 , which meant that respondents who did not have private or public transportation had a tendency not to access FP services 12.5 times higher compared to those who had transportation. Informants, especially mothers who had not become family planning acceptors, stated that they went to the community health center on foot. There were no public or private transportation. From observations it was also known that there were no public transportation facilities operating in 
Table 6. Variables for the final model in multivariate analysis with multiple logistic regression tests

\begin{tabular}{llllll}
\hline No & Variable & B & Wald & $\begin{array}{l}\text { V a l u e } \\
\text { of } p\end{array}$ & OR \\
\hline 1 & Transportation & 2,449 & 17,144 & 0,0001 & 11.6 \\
2 & Significant others influence & 1,197 & 6,083 & 0.014 & 3.3 \\
3 & Belief factor & 1,108 & 3,806 & 0.046 & 3.0 \\
& A constant & $-2,168$ & & &
\end{tabular}

Source: primary data, 2019

Sabu Raijua District. There were no taxibike that could be used by mothers to go to health facilities. Taxibike was only available if it was requested. The price also depended on the distance and the fuel. The average price reached Rp 50,000 for smooth fuel. The problem of transportation in rural communities is that there are lack of transportation infrastructure and facilities, therefore the potential of each rural area is not optimal (Pandey and Sarajar, 2017).

Means of transportation are physical environmental conditions that can facilitate the occurrence of a behavior. According to Interpersonal Behavior Theory by Triandis (cit. Donovan, R. J \& Henley, 2003), behavior is influenced by 3 factors, namely: thelevel at which the behavior has become a habit; intentions which is influenced by emotional responses, social norms, personal normative beliefs and consequences; and conditions that facilitate or which do not support behavior. The absence of transportation facilities can be associated to access to FP services. The results of statistical tests shown that there was a relationship between transportation facilities and access to FP services in poor PUS in Sabu Raijua Regency. The results of the study by Chasanah (2017) state that the role of public health workers is very important and will be optimal if supported by transportation facilities available from home to bring pregnant women to health services so that delays in reaching health facilities can be avoided and can be handled by health workers quickly .

From the results of a qualitative approach, it was also known that there were mothers who did not have objections if they had to walk to healthcare facility because it had become their habit. Mothers were used to walk to school, public facilities, community health center, and other places since they were young.
Therefore, they also did not mind if they had to walk to a health facility, even for about 10-20 minutes, it was not considered as an obstacle. However, there were also mothers who were reluctant to go to health facilities because of lack of transportation facilities, particularly when the mothers did not have their own vehicles. In addition, mothers also had to travel in far distance to get to health facilities. The study by Indrawati (2011) in Pedurungan District showed the percentage of respondents who would access family planning in each condition were $93 \%$ for those living nearby, $90 \%$ for those with available transportation facilities, and $98 \%$ if the public transportation costs were affordable. If the travel time to reach the FP services was more than 1 hour, only $41 \%$ of the respondent accessed family planning compared to 59\% who did not acces FP.

The problem of health services in remote areas could be overcome by the existence of integrated health services which is a combination of all health service activities to patients with adequate coordination and good relationships between individuals in it. Three contributors that can make integration work well are government, technology, and transportation with the main components being the recruitment of local communications that provide health services based on the interests of the community. Access to efficient, strong and safe transportation in developing countries is limited and has an impact on ability of individuals to seek timely health services. (Luti et al. , 2012)

The results of multivariate analysis showed that there are three variables that proved to have significant effect on access to FP services in the poor PUS in Sabu Raijua, namely transport, belief factor, and the influence of significant others.

Based on the calculation results with 
the above equation it could be concluded that poor PUS who had negative belief and significant influence of others (husband, parents, in-laws, and/or friends) and did not have their own transportation or public transportation had a probability of not accessing FP by $92.99 \%$.

\section{Conclusions}

Factors who proved to affect access to FP services in poor PUS in Sabu Raijua were belief with $\mathrm{p}$ value 0.046 , the influence of significant others with $\mathrm{p}$ value of 0.014 , and transportation factors with $\mathrm{p}$ value of 0.0001 . The effect of custom was not shown to have a significant effect on access to FP services with a $p$ value of 1,000 . PUS probably would not access family planning if they had negative beliefs, there were influences of significant others (husband, parents, in-laws, or friends) and did not have their own transportation or public transportation is $92.99 \%$.

\section{Acknowledgement}

The author would like to express gratitude to Ministry of Higher Education, Research, and Tecnology for funding this research. We would like also to thanks all mothers, health care workers, family planning officers and community leaders who had agreed to become informants in this study.

\section{References}

Ariningrum, R. and Sukoco, N. E. W., 2012. 'Studi Kualitatif Pelayanan Kesehatan untuk Kelompok Adat Terpencil (KAT) di Kabupaten Kepulauan Mentawai,, Buletin Penelitian Sistem Kesehatan, 15(3): 250-258.

BKKBN., 2018. Laporan jumlah Akseptor KB Baru dan lama tahun 2015-2017. Kupang: BKKBN Provinsi NTT.

Budisantoso, S. I., 2009. 'Partisipasi Pria Dalam Keluarga Berencana Di Kecamatan Jetis Kabupaten Bantul,' The Indonesian Journal of Health Promotion, 4(2): 103-114. doi: 10.14710/jpki.4.2.103-114.

Chasanah, S. U., 2017. 'Peran Petugas Kesehatan Masyarakat dalam Upaya Penurunan Angka Kematian Ibu Pasca MDGs 2015, Jurnal Kesehatan Masyarakat Andalas, 9(2), p. 73. doi: 10.24893/jkma.9.2.73-79.2015.

Darahim, A., 2010. Kependudukan dan peran pendidikan kependudukan dalam mendukung program KB Nasional. Jakarta: BKKBN.

Donovan, R. J \& Henley, N. (2003) Social Marketing, Principle and practice. Melbourne: IP
Communication.

Dzalva Alfiah, I., 2015. Metode Kontrasepsi Jangka Panjang di Wilayah Kerja Puskesmas Kecamatan Kalideres Tahun 2015.

Ekarini, S. M. B., 2010. Analisis Faktor-Faktor yang Berpengaruh terhadap Partisipasi Pria dalam Keluarga Berencana di Kecamata Selo Kabupaten Boyolali. Universitas Diponegoro. Available at: http://eprints.undip. ac.id/18291/1/Sri_Madya_Bhakti_Ekarini. pdf.

Harahap, Y., Revida, E. and Asfriyati (2013) 'Pengaruh Budaya Akseptor KB terhadap Penggunaan Kontrasepsi IUD di Kecamatan Pantai Labu Kabupaten Deli Serdang': 0-8. Available at: http://repository.usu.ac.id/ handle/123456789/35039.

Hawkins, L. J. and Broaddus, M., 2016. 'The association of attitudes about contraceptives with contraceptive use in a random sample of Colorado women', The Social Science Journal, 53(2): 167-173. doi: 10.1016/j. soscij.2016.03.001.

Hobstetter, M. et al., 2015. "In rape cases we can use this pill": A multimethods assessment of emergency contraception knowledge, access, and needs on the Thailand - Burma border', International Journal of Gynecology and Obstetrics. Elsevier B.V., 130: E37-E41. doi: 10.1016/j.ijgo.2015.05.008.

Hudha Fadhila, N., Widoyo, R. and Elytha, F., 2017. 'Unmed Need Keluarga Berencana Pada Pasangan Usia Subur Di Kecamatan Padang Barat Tahun 2015, Jurnal Kesehatan Masyarakat Andalas, 10(2), p. 151. doi: 10.24893/jkma.10.2.151-156.2016.

Ida Ayu Chandranita Manuaba, Manuaba, I. B. G. F. and Manuaba, I. B. G., 2010. Ilmu kebidanan, penyakit kandungan, dan KB untuk pendidikan bidan. Jakarta: Penerbit Buku Kedokteran.

Indrawati, N. D., 2011. 'Analisis Faktor Kebijakan dan Pengetahuan Tentang Pelayanan KB yang Berhubungan dengan Pemilihan Alat Kontrasepsi IUD pada Ibu PUS Akseptor KB di Kecamatan Pedurungan Kota Semarang, Unimus, 2(3): 1-28.

Luti, I. et al., 2012. 'RUJUKAN KESEHATAN DAERAH KEPULAUAN di daerah terpencil dan kepulauan di Kabupaten mengetahui gambaran kebijakan yang dilakukan rujukan yang melewati laut dan rujukan yang hanya Beberapa jenis alat transportasi yang digunakan dalam proses rujukan ini adala, 01(01): 24-35.

Muhatiah, R., 2012. 'Partisipasi Pria Dalam Program 
Keluarga Berencana (Kb)', Marwah: Jurnal Perempuan, Agama dan Jender, 11(1), p. 1. doi: 10.24014/marwah.v11i1.502.

Noorkasiani; Krisanty, Paula; Mamah, S., 2012. Sosiologi Kebidanan. Jakarta: CV. Trans Info Media.

Notoatmojo, S., 2010. Promosi Kesehatan teori dan Aplikasi. Jakarta: Rineka Cipta.

Pandey, S. V and Sarajar, A. N., 2017. 'Pentingnya Pembangunan Sarana Prasarana Transportasi sebagai Upaya Membangun Desa di Kabuapten Minahasa Utara Provinsi Sulawesi Utara, 5(10): 649-656.

Pinontoan, S., Solang, S. D. and Tombokan, S. G. J., 2014. 'Faktor-Faktor Yang Berhubungan Dengan Penggunaan Alat Kontrasepsi Dalam Rahim Di Puskesmas Tatelu Kabupaten Minahasa Utara, Jurnal Ilmiah Bidan, 2(1): 17-23. Available at: https://media.neliti.com/ media/publications/91085-ID-faktor-faktoryang-berhubungan-dengan-pe.pdf.

Pohan, I. S. (2004) Jaminan Mutu Pelayanan Kesehatan: Dasar-dasar Pengertian dan Penerapan. Jakarta: EGC.

Quinn, D. A., Mitchell, S. J. and Lewin, A., 2017. 'The Role of Teen Mothers' Support Relationships in Maintenance of Contraceptive Use', Journal of Pediatric and Adolescent Gynecology. Elsevier Ltd, 30(1): 35-40. doi: 10.1016/j. jpag.2016.08.008.

Rades, M. and Susianti, M. Y., 2015. 'The Relationship Between Knowledge And Education Of Mom With Using Contraceptive Devices In Satelit Health Care, Bandar Lampung Angka Kelahiran Kasar ( Crude Faktor-faktor', 4: 66-73.

Rafidah, I., 2012. 'Pengaruh Dukungan Suami Terhadap Kepatuhan Akseptor Melakukan KB Suntik', Jurnal Biometrika dan Kependudukan, 1: 72-78.

Rahman, H. et al., 2013. 'Knowledge of, attitudes toward, and barriers to the practice of emergency contraception among women in Sikkim, India, International Journal of Gynecology and Obstetrics, 122(2): 99-103. doi: 10.1016/j.ijgo.2013.03.016.

Raijua, D. K. K. S., 2018. Profil Kesehatan Kabupaten Sabu Raijua.

Sastroasmoro, S., 2011. Dasar-dasar Metodologi Penelitian Klinis. Jakarta: Sagung Seto.
Sirait, A. M., 2015. 'Kepercayaan Lokal Di Indonesia', Kuriositas, edisi VIII.

Sobur, A., 2013. Psikologi umum dalam lintasan sejarah. Bandung: Pustaka Setia.

Strøm-Roum, E. M., Lid, J. and Eskild, A., 2016. 'Use of contraception among women who request first trimester pregnancy termination in Norway', Contraception, 94(2): 181-186. doi: 10.1016/j.contraception.2016.04.005.

Sulistyawati (2011) Asuhan kebidanan pada masa kehamilan. Jakarta: Salemba Medika.

Sunarsih, Nita, E. and Damayati Rinifiya (2015) 'Faktor-Faktor Yang Berhubungan Dengan Penggunaan Alat Kontrasepsi Pada Wanita Usia Subur (Wus)Di Kelurahan Campang Raya Bandar Lampung, Jurnal Kebidanan, 1(3): 110-115. Available at: www.ejurnal. malahayati.ac.id.

Suryawati, C. (2007) 'Faktor Sosial Budaya dalam Praktik Perawatan Kehamilan, Persalinan, dan Pasca Persalinan (Studi di Kecamatan Bangsri Kabupaten Jepara)', The Indonesian Journal of Health Promotion, 2(1): 21-31. doi: 10.14710/jpki.2.1.21-31.

Uddin, J., Pulok, M. H. and Sabah, M. N., 2016. 'Correlates of unmet need for contraception in Bangladesh: does couples' concordance in household decision making matter?', Contraception, 94(1): 18-26. doi: 10.1016/j. contraception.2016.02.026.

Vigoureux, S., Bajos, N. and Ringa, V., 2018. 'Effect of Parent-Daughter Communication about Sex on the Use of Less Effective Contraception among Women from Ages 15-24 Years in France.', Journal of Pediatric and Adolescent Gynecology2, 31(1): 33-39. doi: 10.1016/j. jpag.2017.08.003.

Wahyuningsih, A. et al., 2012. 'Faktor Perilaku yang Mempengaruhi Akseptor Keluarga Berencana Drop Out'.

Winarno, H., 2014. Ilmu Sosial dan Budaya Dasar. Jakarta: Bumi Aksara.

Wulandari, S., 2015. 'Hubungan Faktor Sosial Budaya dengan Keikutsertaan KB IUD di Puskesmas Mergansan Kota Jogjajakarta tahun 2013', Medika Respati, 10: 17-23. Available at: http://medika.respati.ac.id/ index.php/Medika/article/view/35/33. 